\title{
Cukorbetegség és szívelégtelenség: a diabeteses cardiomyopathia
}

\author{
Horváth Viktor dr., Szelke Emese dr., Körei Anna Erzsébet dr., Kempler Péter dr.
}

\begin{abstract}
Osszefoglalas
Bár az ischaemiás szivbetegség továbbra is a kardiovaszkuláris események legföbb kóroki tényezöje cukorbetegekben, a diabeteses cardiomyopathia sem elhanyagolható tényezö a szivelégtelenség kialakulásában diabetesesekben, ezáltal életkilátásaik, életminöségük befolyásolásában. Jóllehet, bármilyen eredetü szivelégtelenség kialakulásának számos lépése átfedést mutat a diabeteses cardiomyopathia patogenezisének lépéseivel, kialakulásának összetevöi, igy kezelésének egyes elemei is eltérhetnek más hátterü szivelégtelenség kezelésétöl. A szerzök összefoglalójukban áttekintik a cukorbetegek szivelégtelensége és a diabeteses cardiomyopathia jelentőségét, a betegség etiológiáját, kialakulásának patomechanizmusát, illetve kezelésének egyes részleteit.
\end{abstract}

Kulcsszavak: diabetes mellitus, szivelégtelenség, diabeteses cardiomyopathia

\section{Diabetes and heart failure. Diabetic cardiomyopathy}

Summary: Although ischaemic heart disease is the most frequent cause of major adverse cardiac events in diabetic patients, diabetic cardiomyopathy is also a not negligible factor in the development of heart failure, and its effect on life expectancy and quality of life is also important. Diabetic cardiomyopathy shares common pathogenetic pathways with many other processes involved in heart failure, however, the details of its development and therefore its treatment in some sense may be different. Here, the authors are aiming to review the importance, etiology, pathomechanism and some special details of the treatment of the heart failure of diabetic patients and diabetic cardiomyopathy.

Key words: diabetes mellitus, heart failure, diabetic cardiomyopathy

\section{Rövidítések:}

AGE: elörehaladott glikációs végtermék (advanced glycation end product); Cl: konfidenciaintervallum (confidence interval); DPP-4: dipeptidil-peptidáz-4; GLP-1: glukagonszerü peptid-1 (glucagon like peptide-1); HbA $_{1 c}$ : hemoglobin $A_{1 c}$ OR: esélyhányados (odds ratio)

A szívelégtelenség kezelése súlyos egészségügyi és gazdasági terheket ró az ellátórendszerre, hiszen a betegség Európában több mint 10 millió, az Egyesült Államokban közel 6 millió beteget érint. ${ }^{1}$ Prevalenciája a felnőtt lakosság körében 0,4-2\% közötti, de 65 éves életkor felett a prevalencia 5-10\%-ra emelkedik. ${ }^{2}$ Ismert, hogy a cukorbetegség gyakorisága világszerte dinamikus növekedést mutat. Az 1995-ös, világszerte mért átlagosan 4\%-os értékről becslések szerint 2025-re 5,4\%-ra emelkedik; ezen betegek halálo- zásának háromnegyede várhatóan kardiovaszkuláris eredetű lesz. ${ }^{3}$ Hazánkban 2001 és 2014 között a 2-es típusú cukorbetegség prevalenciája 70\%-kal emelkedett. ${ }^{4}$

A szívelégtelenség hátterében álló cardiomyopathiák előfordulási gyakorisága különböző. Az Egyesült Államokban a leggyakoribb cardiomyopathia a dilatatív forma, amely 100000 felnőtt közül ötöt érint. ${ }^{5}$ A hypertrophiás cardiomyopathia prevalenciája 1:500 fő; különös jelentősége, hogy sportolókon a hirtelen szívhalál egyik leggyakoribb 
oka. A jobb kamrai aritmogén dysplasia lényegesen ritkább betegség, ugyanakkor földrajzi eloszlása jelentős heterogenitást mutat, így pl. Olaszországban Európa egyéb régióihoz képest gyakoribb. ${ }^{6}$

\section{A cardiomyopathiák osztályozása}

A cardiomyopathia kifejezést először 1957-ben használták a szívbetegségek ezen speciális csoportjának megnevezésére. Az Egészségügyi Világszervezet 1980-as, klinikai entitáson alapuló definíciója szerint cardiomyopathiának nevezték a szívizom azon strukturális rendellenességeit, amelyek hátterében coronariabetegség, magasvérnyomás-betegség vagy szívbillentyü-rendellenesség nem igazolódott. Később a cardiomyopathiák és a specifikus szívizombetegségek közti határ elmosódott, és az 1996-os, patofiziológiai/etiológiai megközelítésen alapuló klasszifikáció már a szívizom-diszfunkcióval járó myocardialis betegségeket nevezte cardiomyopathiának. Ennek alapján dilatatív, hypertrophiás és restriktív cardiomyopathia, valamint - az akkor új csoportként bevezetett - jobb kamrai aritmogén dysplasia mellett megkülönböztettek nem klasszifikált (pl. fibroelastosis, non compacted myocardium, mitochondriális betegséghez társuló) és specifikus cardiomyopathiákat. ${ }^{7}$ Ez utóbbiak közé sorolták többek közt az ischaemiás, valvuláris, gyulladásos, toxikus, peripartum, valamint a metabolikus eredetű szívizombetegségeket. Bár az ez utóbbit részletező felsorolásban a diabetes mellitus is megtalálható, külön említve, diabeteses cardiomyopathiaként a betegség ebben a klasszifikációban sem szerepelt.

A 1990-as évek végétől kezdődően a molekuláris biológia robbanásszerű fejlődése lehetővé tette a cardiomyopathiák osztályozásának átgondolását is. A klinikai megközelítés nehézségét az adta, hogy az egyes cardiomyopathiák jellemzői egymással jelentős átfedést mutatnak. Így pl. a hypertrophiás cardiomyopathia és az infiltratív vagy tárolási betegségekhez társuló cardiomyopathiák egyaránt kamrai dilatáció nélkül megnövekedett falvastagsággal járnak, ugyanakkor igen gyakran restriktív kamrai telődés funkcionális jellemzőit mutatják. A 2006-ban megjelent amerikai klasszifikáció elsősorban nem klinikai metodológián alapuló megközelítés volt, hanem a különböző ioncsatorna-be- tegségek, genetikai rendellenességek irányából próbálta rendszerezni a cardiomyopathiák heterrogén csoportját. ${ }^{8}$ Noha a genetikai abnormalitások ismerete egyáltalán nem volt teljes és azóta is folyamatosan bővül, az ekkor kialakított klasszifikációban (primer és szekunder cardiomyopathiák) azóta sem történtek lényeges változtatások. Klinikai szempontból primer cardiomyopathiának akkor nevezték a betegséget, ha a szívizom érintettsége egyedüli volt, vagy a betegség szempontjából a myocardialis diszfunkció számított elsődlegesnek. Az amerikai klasszifikációtól eltérően a 2008-ban megjelent európai csoportosítás specifikus morfológiai és funkcionális fenotípusokra osztotta a cardiomyopathiákat, amelyeken belül familiáris és non-familiáris alcsoportokat különített el. ${ }^{9}$ Hasonlóan a korábbi beosztásokhoz, mindkét felosztás a diabetes mellitusban jelentkező cardiomyopathiát az endokrin cardiomyopathiák közé sorolja, az amerikai rendszerezésben külön megemlítve ennek familiáris (genetikai) vonatkozását is. Az idézett társasági ajánlásokban ugyan nem szerepel, de a diabeteses cardiomyopathia koncepciója már 1954-ben felvetődött. ${ }^{10}$ Ugyanakkor csak mintegy 20 évvel később jelentek meg újabb bizonyítékok arra vonatkozóan, hogy a cukorbetegség nem csupán a coronariarendszer károsítása által ronthatja a myocardialis funkciót. ${ }^{11}$

\section{A cukorbetegség és a szívelégtelenség összefüggése - epidemiológiai vizsgálatok}

Egyrészt ismert, hogy cukorbetegekben nagyobb eséllyel alakul ki a szívelégtelenség bármely formája, ${ }^{12}$ másrészt a szívelégtelenség kimeneteli mutatói is kedvezőtlenebbek cukorbetegek körében. Már a Framingham vizsgálat egyik elemzése is igazolta, hogy a hasonló korú betegekhez viszonyítva a szívelégtelenség kialakulása cukorbeteg férfiak közt kétszer, nők közt ötször gyakoribb. ${ }^{13}$ Egy másik megfigyelés szerint minden $1 \%$-os $\mathrm{HbA}_{1 \mathrm{c}}$-emelkedés a szívelégtelenség kialakulásának 8\%-os növekedésével jár együtt. ${ }^{14} \mathrm{~A}$ cukorbetegséget megelőző állapotok is összefüggést mutatnak szívelégtelenséggel. A Reykjavik Studyban a normális cukortoleranciával rendelkező személyekben a szívelégtelenség prevalenciája 3,2\% volt, szemben a csökkent cukortoleranciában ész- 
lelt $6.0 \%$-kal és a manifeszt 2-es típusú cukorbetegekben tapasztalt $11,8 \%$-kal. ${ }^{15}$ Mindemellett a diabetes mellitus növeli a dilatatív cardiomyopathia kialakulásának kockázatát és 70-80\%-kal emeli a megtartott ejekciós frakcióval járó szívelégtelenség mortalitását és hospitalizációját is. ${ }^{16} \mathrm{~A}$ megtartott bal kamrai ejekciós frakcióval járó szívelégtelen betegek $30-40 \%$-a pedig egyben cukorbeteg is.

Ez a kétirányú kapcsolat a cukorbetegség és a szívelégtelenség közt más szempontból is megfigyelhető. Amellett, hogy a cukorbetegeken nagyobb eséllyel alakul ki szívelégtelenség, a szívelégtelenség által érintett betegek közt is nagyobb a kockázata 2-es típusú cukorbetegség kialakulásának (OR: 1,4; 95\%-os CI: 1,1-1,8). ${ }^{17}$ Ennek egyik (lehetséges) magyarázata az, hogy a szívelégtelenség növeli az inzulinrezisztenciát (részben a fokozott zsíranyagcsere révén), ami azonban nem mutat direkt összefüggést a bal kamra müködésének zavarával vagy a szívelégtelenségben tapasztalható megemelkedett katekolaminszinttel. ${ }^{18}$

\section{Klinikai jellemzök}

Cukorbetegségben a major cardialis elváltozások és kockázati tényezőik gyakoribb előfordulása nem magyarázza meg önmagában a cukorbetegek szívelégtelenségének megnövekedett kockázatát. ${ }^{19}$ A diabeteses cardiomyopathia első leírása szerint azok a betegek, akik legalább 5-20 évig fennálló cukorbetegségben szenvedtek, jellemzően súlyos szívelégtelenség klinikai jeleivel küzdöttek, aminek hátterében koszorúér-betegség nélküli dilatatív cardiomyopathia patológiai manifesztálódása állt. ${ }^{11}$ További vizsgálatok a szívelégtelenség magasabb incidenciáját találták cukorbetegekben annak ellenére, hogy ezekben a betegekben a szívinfarktus kiterjedése átlagosan kisebb volt a nem cukorbeteg szívelégtelen személyekéhez képest. A diabeteses cardiomyopathia kezdetben használt definícióját később is megtartották kiegészítve azzal, hogy a balkamra-funkció cukorbetegeken észlelhető zavara hátterében hypertonia, billentyübetegség, infiltratív betegség és kongenitális szívbetegség sem mutatható ki. ${ }^{9}$ A mai elképzelés szerint a betegség klinikai megjelenésében annak kezdeti fázisában legalábbis - elsősorban a restriktív fenotípus és diasztolés diszfunkció dominál, minthogy a diabeteses cardiomyopathiában szenvedő betegek elsősorban idősebb, túlsúlyos nőbetegek, normális vagy valamelyest csökkent bal kamrai üregátmérőkkel, megtartott bal kamrai ejekciós frakcióval, vékony bal kamrafallal, meg-

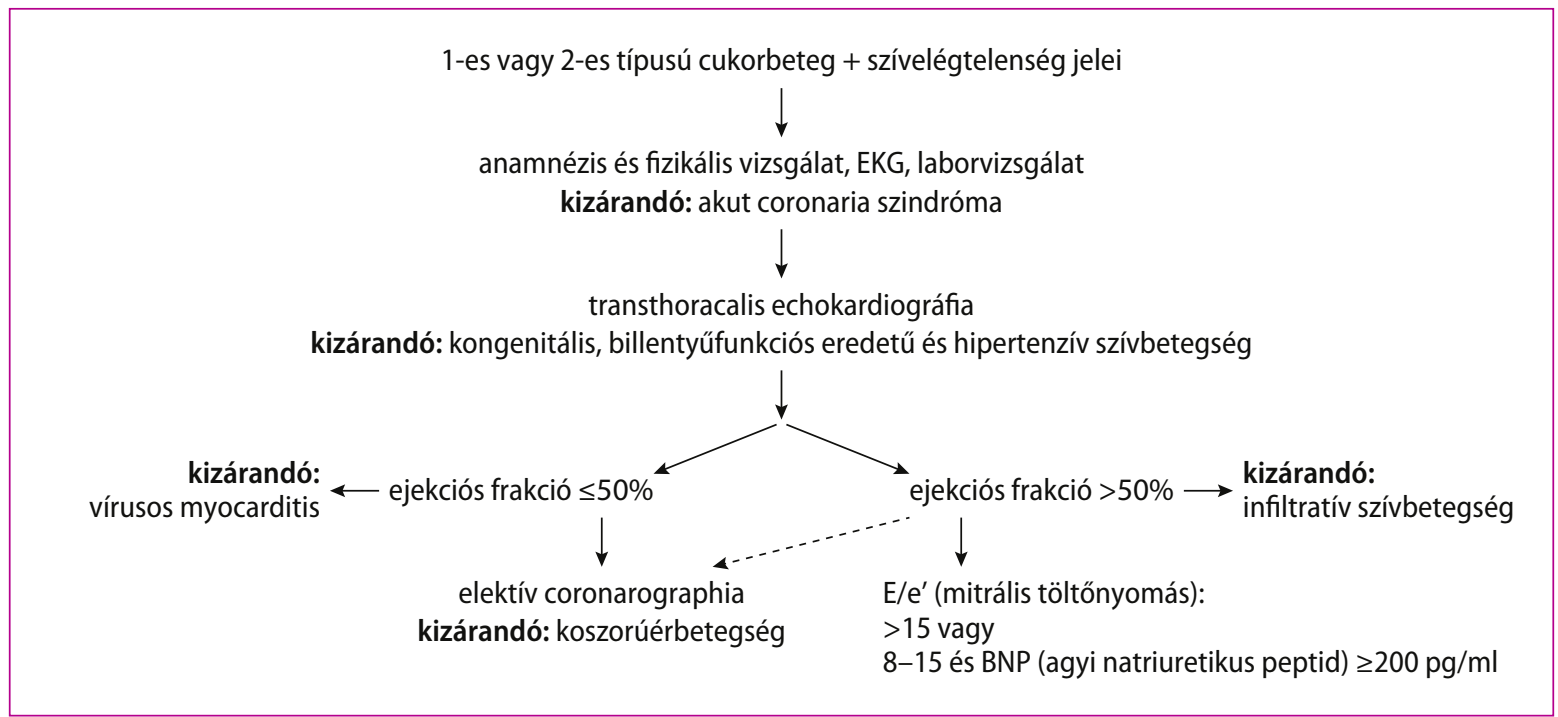

1. ábra. A diabeteses cardiomyopathia diagnosztikája. Az egyes lépések egymásra épülnek, és valamennyi lépés szükséges a diabeteses cardiomyopathia diagnózisának felállitásához 
növekedett bal kamrai töltőnyomással és nagyobb bal pitvarral. ${ }^{20} \mathrm{Ez}$ a restriktív, megtartott bal kamrai szisztolés funkcióval járó forma azonban minden bizonnyal csupán előfutára a csökkent ejekciós frakcióval járó végállapotnak.

Patológiai szempontból vizsgálva az interstitialis fibrosis a legkarakterisztikusabb és korai szöveti elváltozás diabeteses cardiomyopathiában. ${ }^{11}$ További jellemző lehet a myocyták hypertrophiája és necrosisa, az arteriolák hialinos sclerosisa és kapilláris-microaneurismák képződése.

A diagnosztikában a szív ultrahangos vizsgálatának kiemelkedő jelentősége van. A cukorbetegség önmagában befolyással van a bal kamra fenotípusára és funkciójára. Ezek a változások jól mérhetőek hagyományos és újabb (pl. speckle tracking) ultrahangtechnikákkal, még tünetmentes betegekben is. ${ }^{21}$ Úgy tűnik ugyanakkor, hogy az 1-es és 2-es típusú cukorbetegség különböző mértékben és mechanizmusok útján befolyásolja a cardialis funkciót, bár ennek pontos leírása még várat magára. ${ }^{19} \mathrm{~A}$ diabeteses cardiomyopathia diagnosztikus lépéseit az 1. ábra mutatja. Kiemelendő, hogy az egyes diagnosztikus lépések egymást követik, és csak valamennyi diagnosztikai lépés elvégzése után lehet egyértelműen igazolni a diabeteses cardiomyopathia jelenlétét. Mindemellett a megtartott ejekciós frakcióval járó szívelégtelenségben a koszorúérfestés elvégzése nem kötelező, az csak specifikus kórállapotok (pl. instabil angina, crescendo angina) esetén jön szóba. Az infiltratív szívbetegség és a vírusos myocarditis kizárása jelenleg a klinikai gyakorlatban nem terjedt el rutinszerűen, azonban ha gyanújuk felmerül, a specifikus terápia bevezetésének lehetősége miatt elvégzésük ajánlott.

\section{A diabeteses cardiomyopathia hátterében álló lehetséges folyamatok}

Számos mechanizmus szerepe feltételezhető a betegség kialakulásában, amelyek annak egyes szakaszaiban különböző jelentőséggel bírnak. Leegyszerűsítve: a diabeteses cardiomyopathia első szakaszában a hyperglykaemia, a lipotoxicitás és az inzulinrezisztencia szerepe domináns, míg később a csökkent ejekciós frakció kialakulásához elsősorban az autoimmunitás fokozott működé- se vezethet. Az advanced glycation end products (AGE) megjelenése, a neuropathia kialakulása és a mikrovaszkuláris hálózat ritkulása a folyamat mindkét fázisában jelentős szerepet játszik. ${ }^{12}$

$\mathrm{Az}$ autonóm neuropathia lehetséges szerepét már régóta feltételezték, ugyanis a paraszimpatikus tónus csökkenésével kialakuló tachycardia ugyan átmenetileg javítja a myocardium pumpafunkcióját, azonban a myocardium katekolaminraktárainak cukorbetegekben megfigyelhető kiürülésével együtt később a bal kamrai funkciók romlása figyelhető meg.

A hyperglykaemia számos egyéb hatása mellett az endothelsejtek fokozott szuperoxid-produkciójához és a nitrogén-monoxid következményesen csökkent szintéziséhez vezet, ami végső soron a környező szívizomsejtek csökkent distensibilitasát okozza. ${ }^{22}$ A hyperglykaemia következtében megjelenő AGE intramyocardialis depozíciója rontja a bal kamrai relaxációt (myocardialis stiffness), részben a kollagének közti keresztkötések kialakításával, részben a kollagéntermelés fokozásával. ${ }^{23} \mathrm{Az}$ AGE másik jelentős hatása az endothelialis nitrogén-monoxid-produkció és a vazodilatátor válasz csökkentése.

A lipotoxicitás több úton is szerepet játszik a betegség kialakulásában. A szabad zsírsavak megnövekedett kínálatával és felhasználásával együtt járó nagyobb oxigénigény a redukált kapillárishálózat mellett romló cardialis funkciót eredményez, ${ }^{24}$ másrészt a trigliceridek formájában felhalmozódó zsírok a szívizom mechanikus diszfunkcióját fokozzák. ${ }^{17}$

$\mathrm{Az}$ autoimmunitás patofiziológiai szerepét mutatják azok a cukorbeteg állatokon végzett megfigyelések, amelyek indukált szívinfarktust követően a szívizomban $(\alpha-)$ miozin-ellenes T-helper sejtek megjelenését igazolták, majd a fehérjével szembeni tolerancia kialakításával az infarktus méretét csökkentették. Az adatok humán interpretációja segítségével az 1-es típusú diabeteses, infarktust szenvedett betegek 83\%-ában találtak szívizom $(\alpha-)$ miozin elleni antitestet, amely nem cukorbeteg, myocarditisben szenvedő betegekben is jelen volt ugyan, de 2-es típusú cukorbetegekben nem. ${ }^{25}$

$\mathrm{Az}$ inzulinrezisztencia miatt megnövekedett inzulintúlkínálat egyrészt a szívizomsejtek hypertrophiájához vezet (rontva ezzel a bal kamrai relaxációt) ${ }^{26}$ másrészt olyan fehérjék (,uncoupling 
proteins") termelését indítja el, amelyek a szívizomsejtek adenozin-trifoszfát-produkciója helyett a hőtermelés irányába tolják az anyagcserét. Az így kialakuló alacsony foszfokreatinin/adenozin-trifoszfát arány túlsúlyos, illetve cukorbeteg, megtartott bal kamrai funkcióval járó szívbetegeken kimutatható. ${ }^{27}$ Végül megemlítendő, hogy a myocardiumot érő folyamatos oxidatív stressz, epigenetikai változások és a fruktóz direkt myocardialis hatásai ugyancsak a diabeteses cardiomyopathia lehetséges patogenetikai okaiként említhetők. ${ }^{28,29}$

\section{Kezelés}

\section{Nem gyógyszeres kezelés}

A diabeteses cardiomyopathia kezelésének alapelvei a szívelégtelenség egyéb formáinak kezelésével megegyezőek. Ugyanakkor limitált azon tanulmányok száma, amelyek célzottan a diabeteses cardiomyopathia hátterében álló patofiziológiai folyamatok gyógyszeres kezelési lehetőségeit vizsgálta. Összességében elmondható, hogy a betegség kezdeti szakaszát jellemző, megtartott balkamra-funkciójú szívelváltozások kezelésében randomizált vizsgálatok egyelőre nem tudtak egyértelműen előnyös gyógyszereket azonosítani, így különösen ebben a fázisban (de természetesen a betegség későbbi szakaszában is) a megfelelő vérnyomáskontrollnak, a szénhidrát-anyagcsere optimális szinten tartásának, illetve a megfelelő életmódnak van kiemelt jelentősége. Ez utóbbira jó példa egy 16 hétig tartó, jelentős kalóriamegszorítással (450 kcal/nap) járó vizsgálat, amelynek eredménye alapján a szigorú diéta a szívizom diasztolés funkcióját javította, illetve trigliceridtartalmát csökkentette..$^{30}$ Mindemellett a myocardium metabolizmusának súlyos károsodásait a fokozott testmozgás jótékony hatásai csak hosszabb idő (évek) alatt képesek mérsékelni. ${ }^{31}$

\section{Gyógyszeres kezelés}

A cukorbetegség gyógyszeres terápiájában a metformin az első választandó szer. Használatának ritka, de potenciálisan letális szövődménye a laktátacidosis, amely szöveti hypoxia - így szívizom-károsodás - kialakulása esetén elméletileg gyakrabban jelentkezhet. Ezt a félelmet ugyanakkor vizsgálatok nem erősítették meg, ${ }^{32}$ így fokozott figyelemmel, de a gyógyszer hazánkban is alkalmazható szívelégtelenségben szenvedőkön. Egy retrospektív vizsgálat adatai szerint a metformin előrehaladott szívelégtelenségben is biztonságosan alkalmazható készítmény, sőt alkalmazásával tendenciaszerűen ugyan, de jobb túlélés érhető el. ${ }^{33}$

A sulfanylureák alkalmazása az utóbbi években csökkent, de még mindig jelentős. Bár néhány vizsgálat szerint a sulfanylureák nem befolyásolták a szívizom-károsodás kialakulását, ${ }^{34}$ más tanulmányok elsősorban a metforminnal összehasonlítva a szívizom-károsodás kockázatának növekedéséről számoltak be sulfanylureák használata mellett. ${ }^{35}$ Alkalmazásuk hypoglykaemiát okozó hatásuk miatt is fokozott óvatosságot igényel, a magunk részéről ezen gyógyszerek alkalmazását szisztolés szívelégtelenségben nem ajánljuk.

A tiazolidindionok klinikai használatát számos ellentmondás övezi, aminek részletes ismertetése nem célja e közleménynek. Hatásmechanizmusukból adódóan (az angiotenzin II szint csökkentése, vérnyomáscsökkentés, az endotheldiszfunkció javítása) jótékony hatásúak is lehetnének szívbetegségben, de folyadékretineáló hatásuk miatt szívelégtelen betegeken használatuk nem ajánlott.

A glucagonszerű peptid-1 (GLP-1)-receptorok a kardiovaszkuláris rendszer egészében jelen vannak. Állatkísérletes modellben az inkretinalapú kezelés mind a szívelégtelenség tüneteit, mind a túlélést javította, ${ }^{36}$ és humán vizsgálatok is megerősítették a GLP-1 cardialis funkciót javító hatását. ${ }^{37} \mathrm{~A}$ közelmúltban befejeződött LEADER (Liraglutide Effect and Action in Diabetes: Evaluation of Cardiovascular Outcome Results) vizsgálat ugyan nem igazolta a liraglutid egyértelműen előnyös hatását szívelégtelenségben, de a fatális kimenetelű myocardialis infarktus és stroke, illetve a kardiovaszkuláris halálozás szignifikánsan csökkent liraglutid adása mellett. ${ }^{38}$ Ezzel szemben a dipeptidil-peptidáz-4 (DPP-4)-gátló saxagliptin alkalmazása növelte a szívelégtelenség miatti hospitalizációk számarányát, bár az ischaemiás események tekintetében neutrális volt. ${ }^{39}$ A klinikai gyakorlatban igen gyakran alkalmazott DPP4-gátlók közül napjainkban egyelőre egyedül a sitagliptin tekinthető kardiovaszkuláris szempontból maximálisan biztonságosnak. 
A nátrium-glukóz kotranszporter-2 gátló empagliflozin a szívelégtelenség kezelésében sikertörténetnek látszik, ${ }^{40}$ bár egyik gyógyszercsoport tagjairól sincsenek pontos ismereteink arra vonatkozóan, hogy miként befolyásolják a diabeteses cardiomyopathia kialakulásának hátterében álló folyamatokat.

$\mathrm{Az}$ inzulin szívelégtelenségre kifejtett hatására vonatkozóan is ellentmondó adatok láttak eddig napvilágot. Ennek egyik oka, hogy az inzulin a cukorbetegek többségét adó 2-es típusú diabetes mellitus késői szakaszában kerül általában bevezetésre, amikor már többféle mikro- és makrovaszkuláris szövődmény jelen van, így a gyógyszer hatását számos tényező befolyásolja. Diasztolés szívelégtelenségben úgy tűnik, az inzulin neutrális hatással rendelkezik a kardiovaszkuláris események tekintetében, sőt, az inzulinnal elérhető szoros glykaemiás kontroll a szívelégtelenséggel összefüggő kardiovaszkuláris mortalitás növekedéséhez is vezethet. ${ }^{41} \mathrm{~A}$ fentiekből adódóan az inzulinkezelés szívelégtelenségben történő alkalmazására különösen igaz az egyénre szabott kezelés jelentősége.

\section{Jövőbeli lehetőségek a diabeteses szívkárosodás kezelésében}

Bár a szívelégtelenség standard gyógyszeres terápiájának nem része a trimetazidin alkalmazása, ezen készítmény állatkísérletes modellekben lassította a diabeteses cardiomyopathia patológiai jellemzőinek megjelenését. ${ }^{42}$ A trimetazidin annak ellenére képes volt javulást okozni a szívelégtelen 2-es típusú diabeteses betegek balkamra-funkciójában, hogy a coronariaperfúziót nem növelte. ${ }^{43} \mathrm{~A}$ trimetazidin összetett hatásához hozzátartozik még az anginás események számának csökkenése, aminek különösen a neuropathiás betegek silent ischaemiás eseményeinek csökkentésében van klinikai relevanciája. ${ }^{44}$ Hazai munkacsoportok vizsgálatai alapján egyéb hatóanyagok - pl. a szolúbilis guanilátcikláz-aktivátor cinaciguat vagy a foszfofdiészteráz-5-gátló vardenafil - megelőzte, illetve javította a cardialis diszfunkciót kísérletes diabetes mellitusban. ${ }^{45,46}$ A diabeteses szívkárosodás lehetséges terápiás megközelítéséről e lap hasábjain korábban részletes összefoglaló jelent meg. ${ }^{47}$

\section{Következtetések}

A cukorbetegek szívelváltozása népegészségügyi probléma. Az ezen betegekben jelentkező diabeteses cardiomyopathia elsősorban megtartott balkamra-funkcióval járó szívelváltozás klinikai képében manifesztálódik, csak a későbbi szakaszában észlelhető a bal kamra szisztolés funkciójának károsodása. Számos megválaszolatlan kérdés mellett epidemiológiai és randomizált klinikai tanulmányok nem találtak egyelőre olyan, a diabeteses cardiomyopathia korai stádiumában szenvedő betegek mortalitását hatékonyan javító gyógyszert, amely egyidejűleg ezen betegcsoportban a szívelváltozás miatti hospitalizációk számát is eredményesen képes csökkenti. Mindez rávilágít arra, hogy ebben a betegcsoportban az egyénre szabott kezelésnek kiemelt jelentősége van. 


\section{rrodalom}

1. Roger VL, Go AS, Lloyd-Jones DM, Benjamin EJ, Berry JD, Borden WB, et al.: Executive summary: heart disease and stroke statistics - 2012 update: a report from the American Heart Association.; American Heart Association Statistics Committee and Stroke Statistics Subcommittee. Circulation 2012; 125(1): 188-197. doi:10.1161/CIR.0b013e3182456d46

2. McMurray JJ, Adamopoulos S, Anker SD, Auricchio A, Böhm M, Dickensen K, et al.: ESC Guidelines for the diagnosis and treatment of acute and chronic heart failure 2012: The Task Force for the Diagnosis and Treatment of Acute and Chronic Heart Failure 2012 of the European Society of Cardiology. Developed in collaboration with the Heart Failure Association (HFA) of the ESC. Eur Heart J2012; 33(14): 1787-1847. doi:10.1093/eurheartj/ehs104

3. Danaei G, Finucane MM, Lu Y, Singh GM, Cowan MJ, Paciorek CJ, et al: National, regional, and global trends in fasting plasma glucose and diabetes prevalence since 1980: systematic analysis of health examination surveys and epidemiological studies with 370 country-years and 2.7 million participants. Lancet 2011; 378(9785): 31-40. doi:10.1016/50140-6736(11)60679-X

4. Kempler P, Putz Zs, Kiss Z, Wittmann I, Abonyi-Tóth Zs, Rokszin Gy, et al: A 2-es típusú diabetes elöfordulása és költségterheinek alakulása Magyarországon 2001-2014 között - az Országos Egészségbiztositási Pénztár adatbáziselemzésének eredményei. Diabetologia Hungarica 2016; 24: 177-188.

5. Lloyd-Jones D, Adams R, Carnethon M, De Simone G, Ferguson TB, Flegal K, et al: Heart disease and stroke statistics - 2009 update: a report from the American HeartAssociation Statistics Committee and Stroke Statistics Subcommittee. Circulation 2009; 119(3): 480-486. doi:10.1161/CIRCULATIONAHA.108.191259

6. Corrado D, Basso C, Pavei A, Michieli P, Schiavon M, Thiene G: Trends in sudden cardiovascular death in young competitive athletes after implementation of a preparticipation screening program. JAMA 2006; 296: 1593-1601. doi:10.1001/jama.296.13.1593

7. Richardson P, McKenna W, Bristow M, Maisch B, Mautner B, $O^{\prime}$ Connell J, et al.: Report of the 1995 World Health Organization/International Society and Federation of Cardiology Task Force on the Definition and Classification of Cardiomyopathies. Circulation 1996; 93: 841-842.

8. Maron BJ, Jeffrey AC, Gaetano T, Charles TA, Corrado D, Arnett D, et al.: Contemporary definitions and classification of the cardiomyopathies. An American Heart Association Scientific Statement From the Council on Clinical Cardiology, Heart Failure and Transplantation Committee; Quality of Care and Outcomes Research and Functional Genomics and Translational Biology Interdisciplinary Working Groups; and Council on Epidemiology and Prevention. Circulation 2006; 113: 1807-1816. doi:10.1161/CIRCULATIONAHA. 106.174287

9. Elliott P, Andersson B, Arbustini E, Bilinska Z, Cecchi F, Charron P, et al.: Classification of the cardiomyopathies: a position statement from the european society of cardiology working group on myocardial and pericardial diseases. Eur Heart J 2008; 29: 270-276.

10. Lundbaek K: Diabetic angiopathy. A specific vascular disease. Lancet 1954; 263: 377-379. doi:10.1093/eurheartj/ehm342

11. Rubler S, Dlugash J, Yuceoglu YZ, Kumral T, Branwood AW, Grishman A: New type of cardiomyopathy associated with diabetic glomerulosclerosis. Am J Cardiol 1972; 30: 595-602.

12. Dei Cas A, SpigoniV, RidolfiV, Metra M: Diabetes and chronic heartfailure: from diabetic cardiomyopathy to therapeutic approach. Endocr Metab Immune Disord Drug Targets 2013; 13: 38-50. doi:10.2174/1871530311313010006

13. Kannel WB, McGee DL: Diabetes and cardiovascular disease. The Framingham study. JAMA 1979; 241(19): 2035-2038. doi:10.1001/jama.241.19.2035

14. Iribarren C, Karter AJ, Go AS, Ferrara A, Liu JY Sidnex S, et al.: Glycemic control and heart failure among adult patients with diabetes. Circulation 2001; 103(22): $2668-2673$.
15. Thrainsdottir IS, Aspelund T, Thorgeirsson G, Gudnason V, Hardarson T, Malmberg K, et al.: The association between glucose abnormalities and heart failure in the population-based Reykjavik study. Diabetes Care 2005; 28(3): 612-616. doi:10.2337/diacare.28.3.612

16. Aguilar D, Deswal A, Ramasubbu K, Mann DL, Bozkurt B: Comparison of patients with heart failure and preserved left ventricular ejection fraction among those with vs. without diabetes mellitus. Am I Cardiol 2010; 105: 373-377. doi:10.1016/j.amjcard.2009.09.041

17. Després JP, Lemieux I: Abdominal obesity and metabolic syndrome. Nature 2006; 444(7121): 881-887. doi:10.1038/nature05488

18. Swan JW, Anker SD, Walton C, Godsland IF, Clark AL, et Leyva F, et al.: Insulin resistance in chronic heart failure: Relation to severity and etiology of heart failure. I Am Coll Cardiol 1997; 30: 527-532. doi:10.1016/50735-1097(97)00185-X

19. Hölscher ME, Bode C, Bugger H: Diabetic Cardiomyopathy: Does the type of diabetes matter? Int J Mol Sci 2016; 17: 2136-2145. doi: $10.3390 /$ ijms 17122136

20. Seferovic PM., Paulus WJ: Clinical diabetic cardiomyopathy: a two-faced disease with restrictive and dilated phenotypes. Eur Heart J 2015; 36(27): 1718-1727. doi:10.1093/eurheartj/ehv134

21. Loncarevic B, Trifunovic D, Soldatovic I, Vujisic-Tesic B: Silent diabetic cardiomyopathy in everyday practice: a clinical and echocardiographic study. BMC Cardiovasc Dis 2016; 16: 242-252. doi:10.1186/s12872-016-0395-z

22. van Heerebeek L, Hamdani N, Falcao-Pires I, Leite-Moreira AF, Begieneman MP, Bronzwaer JG, et al.: Low myocardial protein kinase $G$ activity in heart failure with preserved ejection fraction. Circulation 2012; 126: 830-839. doi:10.1161/CIRCULATIONAHA. 111.076075

23. van Heerebeek L, Hamdani N, Handoko ML, Falcao-Pires I, Musters RJ, KupreishviliK, et al.: Diastolic stiffness of the failing diabeticheart: importance of fibrosis, advanced glycation end products, and myocyte resting tension. Circulation 2008; 117 (1): 43-51. doi:10.1161/CIRCULATIONAHA.107.728550

24. Mazumder PK, O'Neill BT, Roberts MW, Buchanan J, Yun UJ, Cooksey, RC, et al: Impaired cardiac efficiency and increased fatty acid oxidation in insulin resistant ob/ob mouse hearts. Diabetes 2004; 53(9): 2366-2374. doi:10.2337/diabetes.53.9.2366

25. Gottumukkala RV, Hui Juan LV, Cornivelli L, Wagers AJ, Kwong RY, Bronson R, et al.: Myocardial infarction triggers chronic cardiac autoimmunity in type 1 diabetes. Sci TransI Med 2012; 4: 138ra80. doi:10.1126/scitransImed.3003551

26. Lawlor MA, Alessi DR: PKB/Akt: a key mediator of cell proliferation, survival and insulin responses? J Cell Sci 2001; 114: 2903-2910.

27. Phan IT, Abozguia K, Nallur Shivu G, Mahadevan G, Ahmed I, Williams L, et al.: Heart failure with preserved ejection fraction is characterized by dynamic impairment of active relaxation and contraction of the left ventricle on exercise and associated with myocardial energy deficiency. J Am Coll Cardiol 2009; 54: 402-409. doi:10.1016/j.jacc.2009.05.012

28. Faria A, Persaud SJ: Cardiac oxidative stress in diabetes: Mechanisms and therapeutic potential. Pharmacology and Therapeutics 2017; 172: 50-62. doi:10.1016/j.pharmthera.2016.11.013

29. Singh GB, Sharma R, Khullar M: Epigenetics and diabetic cardiomyopathy. Diab Res Clin Pract 2011; 94(1): 14-21. doi:10.1016/j.diabres.2011.05.033

30. Hammer S, Snel M, Lamb HJ, Jazet IM, van der Meer RW, Pijl H, et al.: Prolonged caloric restriction in obese patients with type 2 diabetes mellitus decreases myocardial triglyceride content and improves myocardial function. J Am Coll Cardiol 2008; 52: 1006-1012. doi:10.1016/j.jacc.2008.04.068

31. Hare JL, Hordern MD, Leano R, Stanton T, Prins JB, Marwick TH: Application of an exercise intervention on the evolution of diastolic dysfunction in patients with diabetes mellitus: efficacy and effectiveness. Circ Heart Fail 2011; 4: 441-449. doi:10.1161/CIRCHEARTFAILURE.110.959312 
32. Eurich DT, Weir DL, Majumdar SR, Tsuyuki RT, Johnson JA, Tjosvold L, et al.: Comparative safety and effectiveness of metformin in patients with diabetes mellitus and heart failure: systematic review of observational studies involving 34,000 patients. Circ Heart Fail 2013; 6: 395-402. doi:10.1161/CIRCHEARTFAILURE. 112.000162

33. Shah DD, Fonarow GC, Horwich TB: Metformin therapy and outcomes in patients with advanced systolic heart failure and diabetes. I Card Fail 2010; 16(3): 200-206. doi:10.1016/j.cardfail.2009.10.022

34. Andersson C, Gislason GH, Jørgensen CH, Hansen PR, Vaag A, Sørensen $\mathrm{R}$, et al: Comparable long-term mortality risk associated with individual sulfonylureas in diabetes patients with heart failure. Diab Res Clin Pract 2011; 94(1): 119-125. doi:10.1016/j.diabres.2011.07.011

35. McAlister FA, Eurich DT, Majumdar SR, Johnson JA. The risk of heart failure in patients with type 2 diabetes treated with oral agent monotherapy. Eur J Heart Fail 2008; 10(7): 703-708. doi:10.1016/j.ejheart.2008.05.013

36. Liu Q, Anderson C, Broyde A, Polizzi C, Fernandez R, Baron A, et al.: Glucagonlike peptide- 1 and the exenatide analogue AC3174 improve cardiac function, cardiac remodeling, and survival in rats with chronic heart failure. Cardiovasc Diabetol 2010; 9: 76-89. doi:10.1186/1475-2840-9-76

37. Poornima I, Brown SB, Bhashyam S, Parikh P, Bolukoglu H, Shannon RP: Chronic glucagon-like peptide-1 infusion sustains left ventricular systolic function and prolongs survival in the spontaneously hypertensive, heart failure-prone rat. Circ Heart Fail 2008; 1(3): 153-160. doi:10.1161/CIRCHEARTFAILURE. 108.766402

38. Marso SP, Daniels GH, Brown-Frandsen K, Kristensen P, Mann JF, Nauck MA, et al.: Liraglutide and cardiovascular outcomes in type 2 diabetes. N Engl J Med 2016; 375(4): 311-322. doi:10.1056/NEJMOa1603827

39. Scirica BM, Bhatt DL, Braunwald E, Steg PG, Davidson J, Hirshberg B, et al. Saxagliptin and cardiovascular outcomes in patients with type 2 diabetes mellitus. N Engl J Med 2015; 369(14): 1317-1326.

40. Zinman B, Wanner C, Lachin JM, Fitchett D, Bluhmki E, Hantel S, et al: Empagliflozin, cardiovascular outcomes, and mortality in type 2 diabetes. $N$ EnglJ Med 2015; 373(22): 2117-2128. doi:10.1056/NEJMoa1504720

41. Smooke S, Horwich TB, Fonarow GC: Insulin treated diabetes is associated with a marked increase in mortality in patients with advanced heart failure. Am Heart J 2005; 149(1): 168-174. doi:10.1016/j.ahj.2004.07.005
42. Zhang L, Ding W, Wang Z, Tang M, Wang F, Li Y et al.: Early administration of trimetazidine attenuates diabetic cardiomyopathy in rats by alleviating fibrosis, reducing apoptosis and enhancing autophagy. J TransI Med 2016; 14: 109-120. doi:10.1186/s12967-016-1068-5

43. Belardinelli R, Cianci G, Gigli M, Mazzanti M, Lacalaprice F: Effects of trimetazidine on myocardial perfusion and left ventricular systolic function in type 2 diabetic patients with ischemic cardiomyopathy. I Cardiovasc Pharmacol 2008; 51: 611-615. doi:10.1097/FJ. 0 b013e31817bdd66

44. Kempler P, Körei AE. Kalandozás a diabetológia és a kardiológia határterületén - fókuszban a trimetazidin. Metabolizmus 2014; 1: 36-42.

45. Mátyás Cs, Barta BA, Németh TB, Oláh A, Hidi L, Birtalan E, et al: A szolubilis guanilát-cikláz aktivátor cinaciguat megelözi a cardialis diszfunkció kialakulását 1-es típusú cukorbetegség patkánymodelljében. Cardiol Hung 2017; 47: 34-45.

46. Radovits T, Bomicke T, Kokeny G, Arif R, Loganathan S, Kécsán K, et al.: The phosphodiesterase- 5 inhibitor vardenafil improves cardiovascular dysfunction in experimental diabetes mellitus. Br J Pharmacol 2009; 156: 909-919. doi:10.1111/j.1476-5381.2008.00098.x

47. Pogátsa G: Újabb megfigyelések a cardiomyopathia diabetica kialakulásával és kezelhelhetóségével kapcsolatban. Diabetologia Hungarica 2004; 12(4): 265-271.

Közlésre érkezett: 2017. január 13.

Közlésre elfogadva: 2017, május 18.

\section{A szerzö levelezési címe:}

\section{Dr. Horváth Viktor József}

Semmelweis Egyetem, I. sz. Belgyógyászati Klinika 1083, Budapest, Korányi Sándor utca 2/a

E-mail: horvath.viktor@mail.semmelweis-univ.hu 